\title{
PEMBATALAN PERKAWINAN DAN PENCEGAHANNYA
}

\author{
Oleh: Faisal ${ }^{1}$
}

\begin{abstract}
Abstrak
Mengingat tidak seharusnya suatu perkawinan itu dibatalkan, karena suatu perkawinan merupakan suatu hal yang bersifat religius dan tidak boleh dipermainkan. Dan karena dalam suatu perkawinan tidak hanya mengikat hubungan satu laki-laki dengan satu perempuan, melainkan mengikat semua keluarga besar yang ada dalam nasab keluarga dan perkawinan yang terjadi tidak hanya hubungan antara manusia dengan manusia (hablu minan nas), melainkan melibatkan hubungan antara manusia dengan Allah SWT., (hablu minallah), sehingga perkawinan tidak mudah dibatalkan. Pembatalan perkawinan merupakan suatu tindakan guna memperoleh keputusan pengadilan yang menyatakan bahwa perkawinan yang dilaksanakan batal. Pengetahuan pihak KUA terhadap keabsahan calon mempelai tidak lain karena akan berimbas pada sah dan tidaknya perkawinan tersebut. Sehingga dipandang penting adanya pencegahan yang dilakukan, guna tidak terjadinya pembatalan perkawinan. Maka diperlukanlah langkah-langkah yang harus ditempuh seperti lembaga pemerintah Kantor Urusan Agama (KUA) supaya dapat mengambil tindakan untuk mengantisipasi terjadinya pembatalan perkawinan.
\end{abstract}

Kata Kunci: Pembatalan perkawinan, pencegahan.

\section{A. Pendahuluan}

Pernikahan selanjutnya disebut perkawinan, merupakan pemberian legimitasi seorang pria dan wanita untuk bisa hidup dan berkumpul bersama dalam sebuah keluarga. Ketenangan atau ketentraman sebuah keluarga ditentukan salah satunya adalah bahwa perkawinan itu harus sesuai dengan dengan tuntutan syariat Islam (bagi orang Islam). Selain itu, ada aturan lain yang mengatur bahwa perkawinan itu harus tercatat di Kantor Urusan Agama (KUA).

Tujuan perkawinan menurut perintah Allah SWT., adalah untuk memperoleh keturunan yang sah dalam masyarakat dengan mendirikan rumah tangga ideal yang damai dan sejahtera dan bahagia yang di dalam Islam sering

\footnotetext{
${ }^{1}$ Penulis adalah salah satu dosen pada Fakultas Syariah IAIN Langsa
} 
disebut dengan keluarga sakinah mawaddah warrahmah. Atau dapat dijelaskan secara terperinci adalah:

1. Menghalalkan hubungan kelamin untuk memenuhi tuntutan hajat tabiat kemanusiaan.

2. Mewujudkan suatu keluarga dengan dasar cinta kasih.

3. Memperoleh keturunan yang sah. ${ }^{2}$

Suatu perkawinan yang sah akan menjadi sarana untuk mencapai cita-cita membina rumah tangga yang bahagia, dimana suami dan isteri serta anak-anak dapat hidup rukun dan tenteram menuju terwujudnya masyarakat sejahtera materiil dan spiritual atau mewujudkan masyarakat yang agamis dan berakhlakul karimah. Di samping itu perkawinan bukanlah semata-mata kepentingan dari orang yang melangsungkannya namun juga kepentingan keluarga dan masyarakat.

Untuk mencapai tujuan dari dilaksanakannya perkawinan, diperlukan adanya peraturan-peraturan yang akan menjadi dasar dan syarat yang harus dipenuhi sebelum dilaksanakannya perkawinan. Salah satu prinsip yang terkandung di dalam Undang-Undang Perkawinan adalah perlindungan bagi calon sekaligus pendewasaan usia individu yang akan melaksanakan perkawinan, artinya bahwa calon suami dan isteri harus matang secara kejiwaan.

Adapun kematangan tersebut terdapat pada Pasal 7 ayat (1) UndangUndang Perkawinan yang menyebutkan bahwa perkawinan hanya diijinkan jika pihak laki-laki telah berusia usia 19 (sembilan belas) tahun dan pihak wanita telah berusia 16 (enam belas) tahun, hal ini menjadi syarat usia minimal yang harus dipenuhi oleh para pihak yang ingin melangsungkan perkawinan.

Selanjutnya ketentuan lain yang menunjukkan prinsip perlindungan bagi para pihak adalah pada Pasal 2 Undang-undang Nomor 1 Tahun 1974 yang menyebutkan:

1. Perkawinan adalah sah, apabila dilakukan menurut hukum masingmasing agamanya dan kepercayaannya.

2 Soemiyati, Hukum Perkawinan Islam dan Undang-undang Perkawinan: Undangundang No. 1 Tahun 1974, tentang Perkawinan, (Yogyakarta: Liberty, 2004), hlm. 12. 
2. Tiap-tiap perkawinan dicatat menurut peraturan perundang-undangan yang berlaku.

Dalam hal pencatatan perkawinan sebagaimana tersebut pada pasal 2 ayat (2) adalah merupakan upaya untuk menjaga kesucian (mitsaqan ghalidzan) aspek hukum yang timbul dari perkawinan. Realisasi dari pencatatan itu, melahirkan Akta Nikah yang masing-masing salinannya dimiliki oleh isteri dan suami. Akta tersebut, dapat digunakan oleh masing-masing pihak bila ada yang merasa dirugikan dari adanya ikatan perkawinan itu untuk mendapatkan haknya. ${ }^{3}$

Seseorang yang akan melangsungkan suatu perkawinan diharuskan mendaftarkan diri terlebih dahulu ke KUA Kecamatan, dengan tujuan untuk mengetahui secara jelas identitas dirinya. Adapun bukti yang menerangkan identitas dirinya adalah Ijazah (bila ada), Akte Kelahiran, Kartu Tanda Penduduk (KTP) atau Kartu keluarga (KK) dan surat yang diminta dari Kepala Desa/Gampong (Geuchik-Aceh) tempat perkawinan itu akan dilaksanakan dan apabila para calon akan melaksanakan perkawinan di luar daerah, maka orang tuanya akan diminta hadir untuk memberikan keterangan dari mereka-mereka yang akan melaksanakan perkawinan tersebut.

Selanjutnya KUA sebagai lembaga yang berwenang mencatat dan mengesahkan perkawinan, baik sah menurut agama maupun pemerintah, berkewajiban mengetahui apakah kedua calon mempelai adalah pasangan yang sah (bukan mahram) atau ternyata keduanya termasuk orang-orang yang dilarang melaksanakan perkawinan menurut agama dan pemerintah, sebagaimana yang diatur dalam Kompilasi Hukum Islam dan Peraturan Perundang-undangan lain tentang Perkawinan. Pentingnya pengetahuan pihak KUA terhadap keabsahan calon mempelai tidak lain karena akan berimbas pada sah dan tidaknya perkawinan tersebut. Jika perkawinan yang sebenarnya tidak sah tersebut dilangsungkan, maka yang terjadi adalah perzinaan, karena termasuk perkawinan yang terjadi adalah perkawinan antar seorang laki-laki dan perempuan yang masih ada hubungan nasab.

\footnotetext{
${ }^{3}$ Zainudin Ali, Hukum Perdata Islam di Indonesia, (Jakarta: Sinar Grafika, 2006), hlm.26.
} 
Maka dengan adanya identitas diri ini atau keterangan status pribadi, bila ada penyalah gunaan atau pemalsuan identitas diri dari pihak yang akan melangsungkan perkawinan, maka akan menjadi persoalan tersendiri bila identitas dan keterangan diri yang digunakan adalah tidak benar atau palsu.

Perbedaan tersebut akan mengakibatkan tidak terpenuhinya syarat yang diharuskan dalam sebuah perkawinan dan dapat merugikan salah satu pihak. Seperti permasalahan yang berkaitan dengan surat keterangan persetujuan kedua calon pengantin yang merupakan syarat perkawinan, atau surat keterangan yang menyatakan bahwa salah satu pengantin adalah duda/janda yang tinggal mati tetapi tidak menyertakan surat kematian, atau surat keterangan persetujuan isteri pertama bagi laki-laki yang ingin berpoligami, atau calon isteri telah hamil duluan dengan laki-laki lain dan lain-lain, di mana kesemuanya itu memungkinkan terjadinya pembatalan perkawinan.

Pembatalan perkawinan tidak seharusnya dilaksanakan karena pembatalan perkawinan sama dengan perceraian di mana memisahkan ikatan perkawinan yang telah sah menurut agama dan negara.

Istilah pambatalan nikah tidak dikenal dalam Islam, akan tetapi hukum Islam hanya mengenal fasakh nikah. Fasakh artinya merusakkan atau membatalkan. Maka fasakh sebagai salah satu sebab putusnya perkawinan ialah merusakkan atau membatalkan hubungan perkawinan yang telah berlangsung. ${ }^{4}$

Sedangkan fasakh dapat disebabkan oleh dua macam yaitu:

1. Disebabkan oleh perkawinan yang tidak memenuhi rukun dan syarat atau terdapat adanya halangan perkawinan.

2. Disebabkan terjadinya sesuatu dalam kehidupan rumah tangga yang tidak memungkinkan rumah tangga itu dilanjutkan. ${ }^{5}$

Dengan demikian, penulis dapat memberikan batasan di sini agar dapat dipahami yang dimaksud dengan pembatalan perkawinan tersebut, maka pembatalan perkawinan penulis artikan sebagai suatu tindakan guna memperoleh

\footnotetext{
4 Ahmad Azhar Basyir, Hukum Perkawinan Islam, (Yogyakarta: UII Press, 2000), hlm. 85 .

5 Amir Syarifuddin, Hukum perkawinan Islam di Indonesia: Antara Fiqh Munakahat dan Undang-undang Perkawinan, (Jakarta: Kencana, 2006), hlm. 253.
} 
keputusan pengadilan yang menyatakan bahwa perkawinan yang dilaksanakan batal.

Mengingat tidak seharusnya suatu perkawinan itu dibatalkan, karena suatu perkawinan merupakan suatu hal yang bersifat religius dan tidak boleh dipermainkan. Dan karena dalam suatu perkawinan tidak hanya mengikat hubungan satu laki-laki dengan satu perempuan, melainkan mengikat semua keluarga besar yang ada dalam nasab keluarga dan perkawinan yang terjadi tidak hanya hubungan antara manusia dengan manusia (hablu minan nas), melainkan melibatkan hubungan antara manusia dengan Allah SWT., (hablu minallah), sehingga perkawinan tidak mudah dibatalkan.

Adapun hal-hal yang tersebut di atas, memang rawan terjadi, sehingga dipandang penting adanya pencegahan yang dilakukan, guna tidak terjadinya pembatalan perkawinan. Maka diperlukanlah langkah-langkah sebagaimana yang ditawarkan oleh peneliti, yakni Kantor Urusan Agama (KUA) supaya dapat mengambil tindakan untuk mengantisipasi terjadinya pembatalan perkawinan dengan cara memanipulasi identitas diri calon pengantin ataupun kekurang telitian dalam menetapkan apakah kedua calon pengantin tersebut boleh melaksanakan perkawinan atau tidak, yang pada akhirnya terjadinya pembatalan perkawinan, walaupun kekuasaan dalam menentukan batal atau tidaknya perkawinan adalah wewenang dari pada Pengadilan Agama atau Mahkamah Syari'ah.

\section{B. Pembatalan Perkawinan}

Adapun sahnya suatu perkawinan, selain harus memenuhi syarat-syarat dan rukun perkawinan, perlu juga diperhatikan ketentuan-ketentuan yang ada dalam hukum perkawinan Islam.

Apabila dikemudian hari diketemukan penyimpangan terhadap syarat sahnya perkawinan, maka perkawinan tersebut dapat dibatalkan. Batalnya perkawinan menjadikan ikatan perkawinan yang telah ada menjadi putus. Ini berarti bahwa perkawinan tersebut dianggap tidak ada bahkan tidak pernah ada, dan suami isteri yang perkawinannya dibatalkan dianggap tidak pernah kawin sebagai suami isteri. 
Pembatalan perkawinan dalam hukum Islam disebut fasakh yang artinya merusakkan atau membatalkan. Jadi fasakh sebagai salah satu sebab putusnya perkawinan ialah merusakkan atau membatalkan hubungan perkawinan yang telah berlangsung. ${ }^{6}$

Terjadinya fasakh menurut mazhab Syafi'iy dan Hanbaly, adalah karena:

1. Pisah karena cacat salah seorang suami istri.

2. Perceraian karena berbagai kesulitan (i'sar) suami.

3. Pisah karena li'an.

4. Salah seorang suami isteri itu murtad.

5. Perkawinan itu rusak (fasad).

6. Tidak ada kesamaam status (sekufu). ${ }^{7}$

Sedangkan menurut mazhab Hanafy, yaitu:

1. Pisah karena suami isteri murtad.

2. Perceraian karena perkawinan itu fasad(rusak).

3. Perpisahan karena tidak seimbangnya status (sekufu) atau suami tidak dapat dipertemukan. ${ }^{8}$

Adapun berdasarkan mazhab Maliky terjadinya fasakh yaitu:

1. Terjadinya li'an.

2. Fasadnya perkawinan.

3. Salah seorang pasangan itu murtad. ${ }^{9}$

Menurut Amir Syarifuddin fasakh dapat disebabkan oleh dua macam yaitu:

1. Disebabkan oleh perkawinan yang tidak memenuhi rukun dan syarat atau terdapat adanya halangan perkawinan.

2. Disebabkan terjadinya sesuatu dalam kehidupan rumah tangga yang tidak memungkinkan rumah tangga itu dilanjutkan. ${ }^{10}$

6 Ahmad Azhar Basyir, Hukum Perkawinan.., hlm. 85.

7 A. Rahman I Doi, Kharakteristik Hukum Islam dan Perkawinan (Jakarta: Grafindo Persada, 1996), hlm. 309.

8 A. Rahman I Doi, Kharakteristik Hukum,..hlm. 309.

9 A. Rahman I Doi, Kharakteristik Hukum. hlm. 310.

${ }^{10}$ Amir Syarifuddin, Hukum perkawinan ... hlm. 253. 
Selanjutnya Amir Syarifuddin menambahkan bahwa ada beberapa faktor yang menyebabkan terjadinya pembatalan perkawinan atau fasakh, yaitu: ${ }^{11}$

\section{Syiqaq}

Yaitu adanya pertengkaran antara suami isteri yang terus menerus. sebagaimana firman Allah di dalam surat an Nisa ayat 35:

Artinya: dan jika kamu khawatirkan ada persengketaan antara keduanya, Maka kirimlah seorang hakam dari keluarga laki-laki dan seorang hakam dari keluarga perempuan. jika kedua orang hakam itu bermaksud Mengadakan perbaikan, niscaya Allah memberi taufik kepada suami isteri itu. Sesungguhnya Allah Maha mengetahui lagi Maha Mengenal. (QS. an Nisa': 35)

\section{Cacat}

Yaitu cacat yang terdapat pada diri suami atau istri, baik cacat jasmani atau cacat rohani atau jiwa. Cacat tersebut mungkin terjadi sebelum perkawinan, namun tidak diketahui oleh pihak lain atau cacat yang berlaku setelah terjadi akad perkawinan, baik ketahuan atau terjadinya itu setelah suami isteri bergaul atau belum.

3. Suami tidak mampu memberi nafkah

Nafkah yakni berupa nafkah lahir atau nafkah batin, yang menyebabkan penderitaan dipihak isteri.

\section{Mafqud (Suami ghaib)}

Suami ghaib adalah suami meninggalkan tempat tetapnya dan tidak diketahui kemana perginya dan di mana keberadaannya dalam waktu yang lama.

5. Melanggar perjanjian dalam perkawinan

\footnotetext{
${ }^{11}$ Amir Syarifuddin, Hukum perkawinan.., hlm. 245.
} 
Sebelum akad nikah suami dan isteri dapat membuat perjanjian perkawinan. Pelanggaran terhadap perjanjian perkawinan tersebut dapat menyebabkan terjadinya pembatalan perkawinan.

Pembahasan tentang pembatalan perkawinan secara lengkap dan terperinci telah dijelaskan di dalam Undang-undang Nomor 1 Tahun 1974 Tentang Perkawinan Pasal 22, dinyatakan dengan tegas bahwa "perkawinan dapat dibatalkan, apabila para pihak tidak memenuhi syarat-syarat untuk melangsung-kan perkawinan." Sedangkan di dalam Kompilasi Hukum Islam telah diatur pada pasal 70 sampai Pasal 76. ${ }^{12}$

Alasan-alasan yang dapat diajukan untuk pembatalan perkawinan adalah:

1. Perkawinan yang dilangsungkan di hadapan pegawai pencatat perkawinan yang tidak berwenang.

2. Wali nikah yang melakukan perkawinan itu tidak sah,

4. Perkawinan dilangsungkan tanpa dihadiri oleh 2 (dua) orang saksi,

5. Perkawinan dilangsungkan dibawah ancaman yang melanggar hukum,

6. Ketika perkawinan berlangsung terjadi salah sangka mengenai diri suami atau istri. ${ }^{13}$

Namun, walaupun terdapat alasan untuk melakukan pembatalan perkawinan, tetapi tidak semua orang dapat mengajukan pembatalan perkawinan. Sedangkan pembatalan perkawinan dapat diajukan oleh salah satu dari suami istri yang bersangkutan, antar lain karena anggota keluarga sedarah dalam garis lurus ke atas dari suami atau istri. Selain itu, dapat pula diajukan oleh pejabat yang berwenang atau pejabat yang ditunjuk atau orang lain yang berkepentingan hukum secara langsung terhadap perkawinan tersebut.

Secara jelas tentang pihak-pihak yang dapat mengajukan pembatalan perkawinan di dalam UU Perkawinan yaitu diatur dalam Pasal 23 dan Pasal 24. ${ }^{14}$ Sedangkan dalam Kompilasi Hukum Islam diatur dalam Pasal 73. ${ }^{15}$ Pihak-pihak tersebut antara lain:

\footnotetext{
${ }^{12}$ Tim Redaksi Nuasa Aulia, Kompilasi Hukum Islam..., hlm. 21-22.

${ }^{13}$ Undang-undang No. 1 Tahun 1974 tentang Perkawinan Pasal 26 ayat (1).

${ }^{14}$ Lihat Undang-undang No. 1 Tahun 1974 tentang Perkawinan.

${ }^{15}$ Lihat Kompilasi Hukum Islam.
} 
a. Para keluarga dalam garis keturunan lurus ke atas dari suami atau isteri. Misalnya bapak atau ibu dari suami atau isteri, kakek atau nenek dari suami atau isteri.

b. Suami atau isteri. Artinya bahwa inisiatif permohonan itu dapat timbul dari suami atau isteri saja, atau dapat juga dari keduanya secara bersama-sama dapat mengajukan pembatalan perkawinan.

c. Pejabat yang berwenang hanya selama perkawinan belum diputuskan. Pejabat yang ditunjuk ditentukan lebih lanjut dalam peraturan perundangundangan (Pasal 16 ayat (2)), namun sampai saat ini urusan tersebut masih dipegang oleh PPN atau Kepala Kantor Urusan Agama, Ketua Pengadilan Agama atau Ketua Pengadilan Negeri.

d. Setiap orang yang mempunyai kepentingan hukum secara langsung terhadap perkawinan tersebut, tetapi hanya setelah perkawinan tersebut diputuskan.

\section{Pencegahan Pembatalan Perkawinan}

Dalam mencegah terjadi pembatalan perkawinan, maka hal yang dapat dilakukan oleh lembaga pemerintah seperti KUA adalah sebagai berikut:

1. Memeriksa kelengkapan administrasi pendaftaran dan melakukan pemeriksaan status/kebenaran data pada berkas pendaftaran pada saat pendaftaran dengan teliti dan sesuai dengan peraturan.

Orang yang mendaftar nikah ke KUA ialah wali dan calon mempelai wanita. Supaya pihak KUA juga dapat langsung meneliti apakah benar calon penganti wanita adalah anak kandung dari wali atau wali adalah wali yang sah bagi calon mempelai wanita.

Adapun syarat administrasi yang harus diserahkan, sebagai berikut: ${ }^{16}$

1. Surat persetujuan calon mempelai.

2. Akta kelahiran/Surat keterangan asal usul.

3. Surat keterangan orang tua

4. Surat keterangan untuk nikah (Model N1)

5. Surat izin kawin bagi anggota TNI/POLRI. hlm. 37-38

${ }^{16}$ Dirjen Bimas Islam Depag. RI, Pedoman Penghulu (Jakarta: Dirjen Bimas RI, 2008), 
6. Akta Cerai, bila janda/duda.

7. Surat kematian suami/isteri, bila janda/dudanya karena kematian salah seorang.

8. Dispensasi dari pengadilan, bila belum cukup umur.

9. Dispensasi dari Camat, bila pernikahannya kurang 10 hari sejak pengumuman.

10. Surat keterangan tidak mampu, bila mereka tidak mampu.

11. Bagi warga asing: Paspor, Surat izin dari kedutaan dan surat status dari negaranya.

Dalam hal pendaftaran nikah harus dilakukan oleh wali, calon mempelai wanita, dan calon mempelai pria. Berkaitan dengan siapa yang harus mendaftarkan nikah telah diatur dalam Pasal 4 Peraturan Pemerintah No. 9 Tahun 1975 tentang Pelaksanaan Undang-undang No. 1 Tahun 1974 tentang Perkawinan. Di dalam pasal tersebut dijelaskan bahwa orang yang mendaftar nikah/orang yang memberitahukan kehendak nikah ke KUA/PPN adalah calon mempelai, orang tua, atau wakilnya. ${ }^{17}$

\section{Memasang pengumuman kehendak nikah}

Sebelum kehendak nikah tersebut dipublikasikan melalui pengumuman, pihak KUA sudah harus menyatakan bahwa perkawinan bisa dilanjutkan. Apabila ada pihak lain yang menemukan keganjilan atau kesalahan di antara kedua calon mempelai setelah mengetahui pengumuman tersebut dapat langsung menghubungi KUA.

Memasang pengumuman kehendak nikah, sebagaimana yang disebutkan dalam Pasal 8 Peraturan Pemerintah No. 9 Tahun 1975, sebagai berikut:

"Setelah dipenuhinya tatacara dan syarat-syarat pemberitahuan serta tiada sesuatu halangan perkawinan, Pegawai Pencatat menyelenggarakan pengumuman tentang pemberitahuan kehendak melangsungkan perkawinan dengan cara menempelkan surat pengumuman menurut formulir yang ditetapkan pada kantor Pencatatan Perkawinan pada suatu tempat yang sudah ditentukan dan mudah dibaca oleh umum."18

Maksud daripada pengumuman kehendak nikah adalah untuk memberi kesempatan kepada umum untuk mengetahui dan mengajukan keberatan-

\footnotetext{
${ }^{17}$ Lembaran Negara Republik Indonesia Tahun 1975 Nomor 12.
}

${ }^{18}$ Lembaran Negara Republik Indonesia Tahun 1975 Nomor 12. 
keberatan bagi dilangsungkannya suatu perkawinan apakah yang demikian itu diketahuinya bertentangan dengan hukum agamanya dan kepercayaannya itu yang bersangkutan atau bertentangan dengan peraturan perundangundangan lainnya.

Mengenai pengumuman kehendak nikah tidak hanya diatur dalam Peraturan Pemerintah No. 9 Tahun 1975, tetapi dalam Pasal 13 Peraturan Menteri Agama No. 11 Tahun 2007 juga dijelaskan bahwa pengumuman kehendak nikah harus dipasang selama 10 hari dan dilakukan di tempat tertentu di KUA atau di tempat-tempat lain yang mudah diketahui oleh umum di tempat tinggal masingmasing calon mempelai. ${ }^{19}$

3. Memeriksa kembali kebenaran pernyataan calon mempelai atau wali pada saat pendaftaran sebelum proses akad nikah dilaksanakan.

Adapun cara yang digunakan adalah mengajukan pertanyaan dengan mencocokkan dengan surat-surat dan syarat administratif lainnya, seperti ijazah, KK, KTP, dan lain sebagainya. Menghadirkan kedua calon mempelai pada saat akad nikah dan mengidentifikasi suara.

\section{Mengumumkan kepada saksi bahwa calon pengangtin dapat segera dinikahkan} dan sebelumnya memberitahu saksi mengenai fungsi dan tugasnya dalam proses akad nikah.

Sebelum akad nikah dilaksanakan, penghulu memberi pengarahan dan penjelasan kepada seluruh hadirin yang dijadikan sebagai saksi bahwa mereka bertugas mengawasi apakah rukun dan syarat perkawinan yang akan dilaksanakan tersebut telah terpenuhi atau apakah terdapat halangan-halangan perkawinan.

Adapun jumlah saksi adalah dua orang, dengan syarat-syarat tertentu, di antaranya saksi harus laki-laki, muslim, minimal berusia 19 tahun, berakal, merdeka, dan adil, sebagaimana yang diatur dalam Pasal 19 ayat (1) dan (2) Peraturan Menteri Agama No. 11 Tahun 2007. ${ }^{20}$

Penghulu menjelaskan bahwa para saksi berhak menunda atau membatalkan akad nikah jika mereka mengetahui ada rukun atau syarat yang

\footnotetext{
${ }^{19}$ Berita Negara Republik Indonesia Tahun 2007 Nomor 5.

${ }^{20}$ Berita Negara Republik Indonesia Tahun 2007 Nomor 5.
} 
tidak terpenuhi atau terdapat penghalang perkawinan. Apabila saksi menyatakan perkawinan tidak sah, maka penghulu (Kepala KUA) tidak akan meresmikan perkawinan tersebut.

\section{Memberitahu kepada seluruh hadirin mengenai syarat dan rukun nikah.}

Memberitahu kepada seluruh hadirin mengenai syarat dan rukun nikah, tidak lain supaya mereka juga dapat mengidentifikasi apakah benar kedua calon mempelai adalah pasangan yang sah atau terdapat hal-hal yang menjadi penghalang perkawinan atau tidak.

Sama halnya dengan memberitahu saksi mengenai fungsi dan tugasnya dalam majelis perkawinan, memberitahu para hadirin sebagai saksi nikah mengenai rukun dan syarat nikah merupakan salah satu upaya mengindari terjadinya pembatalan perkawinan.

6. Melakukan penolakan nikah jika ditemukan penghalang nikah.

Berdasarkan data yang diperoleh pada saat pendaftaran nikah dan pada saat pemeriksaan berbeda dan ditemukan penghalang nikah, maka KUA tidak dapat melakukan pernikahan dan melakukan penolakan.

Misalnya dalam hal calon pengantin tidak cukup umur, sesuai dengan ketentuan dalam Undang-undang No. 1 Tahun 1974 bahwa seseorang yang hendak melangsungkan perkawinan harus berusia minimal 21 tahun. ${ }^{21}$ Apabila kurang dari itu harus mendapat dispensasi dari Pengadilan. ${ }^{22}$

Mengenai penolakan nikah ini berdasarkan Bab X tentang Pencegahan Perkawinan Pasal 64 Kompilasi Hukum Islam yang berbunyi:

"Pejabat yang ditunjuk untuk mengawasi perkawinan berkewajiban mencegah perkawinan bila rukun dan syarat perkawinan tidak terpenuhi."23

Selain itu, disebutkan juga dalam Bab VI tentang Penolakan Kehendak Nikah Pasal 12 ayat (1) dan (2) Peraturan Menteri Agama No. 11 Tahun 2007 bahwa apabila syarat-syarat perkawinan tidak terpenuhi atau terdapat halangan

\footnotetext{
${ }^{21}$ Lembaran Negara Republik Indonesia Tahun 1974 Nomor 1.

${ }^{22}$ Berita Negara Republik Indonesia Tahun 2007 Nomor 5.

${ }^{23}$ Instruksi Presiden Nomor 1 Tahun 1991.
} 
menikah, maka kehendak perkawinannya ditolak dan tidak dapat dilasaksanakan. Kemudian penolakan perkawinan tersebut diberitahukan kepada calon suami dan wali nikah disertai alasan-alasannya. ${ }^{24}$

\section{Menanyakan setuju tidaknya calon mempelai untuk menikah.}

Di antara syarat perkawinan sesuai yang diatur dalam Pasal 6 ayat (1) Undang-undang Perkawinan No. 1 Tahun 1974 ialah bahwa perkawinan harus berdasarkan atas persetujuan kedua mempelai. Begitu pula yang disebutkan dalam Pasal 6 Peraturan Menteri Agama No. 11 Tahun 2007.

Oleh karena itu, pada saat pemeriksaan perkawinan penghulu juga menanyakan mengenai setuju atau tidaknya calon mempelai untuk menikah. Apabila kedua calon mempelai atau salah satunya tidak berkehendak untuk menikah, maka perkawinan tidak dapat dilangsungkan. Ini menunjukkan bahwa KUA memperhatikan dan melaksanakan aturan yang telah ditetapkan dalam peraturan perundang-undangan.

Setelah pemeriksaan pada saat pemberitahuan kehendak menikah (pendaftaran), dan KUA tdak menemukan adanya hal-hal yang menjadi penghalang menikah, maka tugas KUA selanjutnya ialah mengumumkan kehendak menikah tersebut dalam jangka waktu 10 hari sebelum pelaksanaan akad nikah. Dalam pengumuman kehendak nikah disebutkan identitas calon mempelai pria, calon mempelai wanita dan orang tua masing-masing, wali, waktu pelaksanaan akad nikah, dan nama suami/isteri terdahulu.

Apabila selama 10 hari itu tidak ada pihak yang melapor adanya penghalang perkawinan, maka KUA dapat melaksanakan akad nikah. Sebelum pelaksanaan akad nikah, KUA memeriksa kembali hasil pemeriksaan pada saat pendaftaran (cross check) dan masih memberi kesempatan kepada semua yang hadir apabila terdapat keberatan-keberatan. Ini adalah upaya-upaya KUA yang dilakukan berdasarkan peraturan perundang-undangan.

Dengan demikian, maka KUA dapat melaksanakan tugas dan fungsinya sesuai perundang-undangan, di antaranya mencatat setiap orang yang melaporkan

\footnotetext{
${ }^{24}$ Berita Negara Republik Indonesia Tahun 2007 Nomor 5.
} 
kehendak menikah, serta memeriksa kelengkapan administrasi yang merupakan sarana dalam memeriksa status kedua calon mempelai beserta wali, khususnya yang berkaitan dengan rukun dan syarat perkawinan, yang kesemuanya tersebut dapat mencegah terjadinya pembatalan pernikahan.

\section{Kesimpulan}

Pembatalan perkawinan tidak seharusnya dilaksanakan karena pembatalan perkawinan sama dengan perceraian di mana memisahkan ikatan perkawinan yang telah sah menurut agama dan negara. Istilah pambatalan nikah tidak dikenal dalam Islam, akan tetapi hukum Islam hanya mengenal fasakh nikah. Fasakh artinya merusakkan atau membatalkan. Maka fasakh sebagai salah satu sebab putusnya perkawinan ialah merusakkan atau membatalkan hubungan perkawinan yang telah berlangsung. Sedangkan fasakh dapat disebabkan oleh dua macam yaitu: Pertama, Disebabkan oleh perkawinan yang tidak memenuhi rukun dan syarat atau terdapat adanya halangan perkawinan. Kedua, Disebabkan terjadinya sesuatu dalam kehidupan rumah tangga yang tidak memungkinkan rumah tangga itu dilanjutkan

\section{DAFTAR PUSTAKA}

A. Rahman I Doi, Kharakteristik Hukum Islam dan Perkawinan, Jakarta: Grafindo Persada, 1996.

Ahmad Azhar Basyir, Hukum Perkawinan Islam, Yogyakarta: UII Press, 2000. 
AL-QADHA Jurnal Hukum Islam Dan Perundang-undangan

Amir Syarifuddin, Hukum perkawinan Islam di Indonesia: Antara Fiqh Munakahat dan Undang-undang Perkawinan, Jakarta: Kencana, 2006.

Berita Negara Republik Indonesia Tahun 2007 Nomor 5.

Dirjen Bimas Islam Depag. RI, Pedoman Penghulu, Jakarta: Dirjen Bimas RI, 2008.

Instruksi Presiden Nomor 1 Tahun 1991.

Lembaran Negara Republik Indonesia Tahun 1975 Nomor 12.

Lembaran Negara Republik Indonesia Tahun 1974 Nomor 1.

Soemiyati, Hukum Perkawinan Islam dan Undang-undang Perkawinan: Undangundang No. 1 Tahun 1974, tentang Perkawinan, Yogyakarta: Liberty, 2004.

Undang-undang No. 1 Tahun 1974 tentang Perkawinan Pasal 26 ayat (1).

Zainudin Ali, Hukum Perdata Islam di Indonesia, Jakarta: Sinar Grafika,2006. 